\title{
The effect of Christianity on the tradition and culture of the Idoma people of Nigeria: A comparative study
}

\begin{tabular}{|c|c|}
\hline \multicolumn{2}{|c|}{$\begin{array}{l}\text { Emmanuel C. Anizoba } \\
\text { Edache M. Johnson }^{1,2}\end{array}$} \\
\hline \multicolumn{2}{|c|}{$\begin{array}{l}\text { Affiliations: } \\
{ }^{1} \text { Department of Religion, } \\
\text { Faculty of the Social Sciences, } \\
\text { University of Nigeria, } \\
\text { Enugu, Nigeria }\end{array}$} \\
\hline \multicolumn{2}{|c|}{$\begin{array}{l}{ }^{2} \text { Department Religion } \\
\text { Studies, Faculty of Theology } \\
\text { and Religion, University } \\
\text { of Pretoria, Pretoria, } \\
\text { South Africa }\end{array}$} \\
\hline \multicolumn{2}{|c|}{$\begin{array}{l}\text { Description: This research is } \\
\text { part of the research project, } \\
\text { 'Religion, Theology and } \\
\text { Education', directed by Prof. } \\
\text { Dr Jaco Beyers, Head of the } \\
\text { Department of Religion } \\
\text { Studies, Faculty of Theology } \\
\text { and Religion, University of } \\
\text { Pretoria, Pretoria. }\end{array}$} \\
\hline \multicolumn{2}{|c|}{$\begin{array}{l}\text { Corresponding author: } \\
\text { Emmanuel Anizoba, } \\
\text { emmanuel.anizoba@unn. } \\
\text { edu.ng }\end{array}$} \\
\hline \multicolumn{2}{|c|}{$\begin{array}{l}\text { Received: } 31 \text { Aug. } 2021 \\
\text { Accepted: } 11 \text { Nov. } 2021 \\
\text { Published: } 17 \text { Dec. } 2021\end{array}$} \\
\hline \multicolumn{2}{|c|}{$\begin{array}{l}\text { How to cite this article } \\
\text { Anizoba, E.C. \& Johnson, E.M. } \\
\text { 2021, 'The effect of } \\
\text { Christianity on the tradition } \\
\text { and culture of the Idoma } \\
\text { people of Nigeria: A } \\
\text { comparative study', } \\
\text { HTS Teologiese Studies/ } \\
\text { Theological Studies 77(4), } \\
\text { a7111. https://doi.org/ } \\
\text { 10.4102/hts.v77i4.7111 }\end{array}$} \\
\hline \multicolumn{2}{|c|}{$\begin{array}{l}\text { Copyright: } \\
\text { (C) 2021. The Authors. } \\
\text { Licensee: AOSIS. This work } \\
\text { is licensed under the } \\
\text { Creative Commons } \\
\text { Attribution License. }\end{array}$} \\
\hline \multirow[b]{2}{*}{ 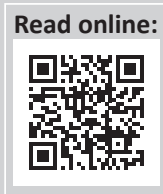 } & \\
\hline & $\begin{array}{l}\text { Scan this QR } \\
\text { code with your } \\
\text { smart phone or } \\
\text { mobile device } \\
\text { to read online. }\end{array}$ \\
\hline
\end{tabular}

Some of the traditions and cultural beliefs and practices of the Idoma people of Nigeria have been influenced both positively and negatively as a result of the advent of Christianity in the area. The aim of this research is to investigate some of the cultural beliefs and practices of the Idoma people before the advent of Christianity, the people's response to the new faith and the propelling factors behind the responses of the people. In doing so, a comparative study on these beliefs and practices after the advent of Christianity in Idoma traditional society was done. The study adopts a qualitative phenomenological research design and descriptive method for data analysis. Personal interviews form a primary source of data collection, while the secondary source includes library sources. This method of study was chosen to allow the data collected to speak for themselves without any interference from the researchers. The study unveils that the advent of Christianity in the Idoma traditional society had some impact and consequences on the traditional and cultural practices of the people, such as death and burial ceremonies, the Aje-alekwu festival and widowhood practices among others. The study recommends that there should be a synergy between Idoma traditional beliefs and practices and Christianity for peaceful co-existence, progress and development in the area.

Contribution: It is erroneously believed that in the contemporary society, traditional religious practices are going to die and become a thing of the past. However, one would observe from this study that Idoma people still hold their traditional beliefs and practices in high esteem despite the influence of Christianity in the area.

Keywords: effect; Christianity; tradition; culture; worldview.

\section{Introduction}

Some of the western influences on the Idoma traditional belief system are reflected on modernity, science and technology, religion, industrialisation, urbanisation, and so on. Anizoba and Johnson (2021:5) observed that the Idoma tradition is complex in nature and even if certain aspects of the tradition died out, other aspects still survived and many of them were changed or transformed by Christianity to meet the needs of the changing times. The aim of the research is to do a comparative study of the effect of Christianity on the tradition and culture of the Idoma people of Nigeria. Mbiti in Agha (2012) remarked that some of the traditional beliefs and practices Christianity tries to influence still remain human problems, especially those concerned with birth, marriage, death, the hereafter, suffering, sickness and so on. Hence, Idoma traditions and its belief system will continue to have something to say on these issues of human life, even if Christianity and scientific ways of thought have either positive or negative influence on the cosmology as a result of the advent of Christianity in the area. The study will be of immense importance for the Idoma people and their cosmology. It will critically evaluate the cultural beliefs and practices of the Idoma people, especially with regard to the extent of influence of Christianity on their cultural beliefs and practices such as death and burial ceremonies, Aje-alekwu festival, widowhood practices, child naming, and belief in polygamous festivals, marriage and so on. The study will no doubt help the Nigerian Ministry of Education in the area of curriculum development in tertiary institutions, secondary schools and primary schools as the case may be where African traditional religion (ATR) will be captured. Again, students of ATR who may wish to embark on a similar topic will see the work very useful. It will also document the cultural changes among the traditional Idoma people since the appearance of Christian missionaries. Traditional religious worshipers in the area, who still hold the beliefs and practices in high esteem, will also benefit from this study.

\section{Methodology}

The study adopts a qualitative phenomenological research design and descriptive method of data analysis. Personal interviews form the primary sources of data collection with 25 informants 
chosen at random for the interview (see Table 1). The informants were diverse in terms of distribution of gender, occupation and religious affiliation with particular regard to Christianity and ATR in Idoma. The interview questions were semi-structured, which allowed the researcher to follow up on similar groups of interview questions based on the respondent's responses. All relevant issues guiding the conduct of interview were followed. It was made known to the informants that the information gotten from them will be solely used for this research.

\section{Worldview of Idoma people before the advent of Christianity}

Anizoba and Johnson (2021) observed that like most communities in Africa, the Idoma people from Nigeria and Benue state have a lot in common with other traditional societies, even though certain cultural traits still slightly distinguish them from other cultures. These traits are an integral part of the uniqueness of the Idoma people, and include among others traits such as dressing, title taking, marriage, food, childbirth/naming ceremony, death, burial rites ceremony and so on. Therefore, the Idoma world view includes: belief in spirit, belief in magic and medicine, ancestral curses, among others. It is also believed in Idoma cosmology that there are some mystic forces in the universe which can be tapped and utilised to bring about some effects, good and bad (Omoregbe 1999:20). Omoregbe observed that some people who are able to access these forces (supernatural powers), make use of them. Some use them for good purposes, such as healing and solving difficult problems of mankind, for example, priest-physicians. Many people, however, use these powers for evil purposes, such as causing harm and disease to other people (Omoregbe 1999).

\section{Effect of Christianity on the traditions and culture of Idoma people of Nigeria}

The effects of Christianity on the tradition and culture of Idoma people of Nigeria are as follows:

\section{Cultural religious effects}

The impact of Christianity on all aspects of the beliefs and customs of the people may not come as a surprise when it is recalled that the overriding aim of the missionary agents was to suppress and supplant the existing traditional religion and customs, and replace them with the imported religion of Christianity. Adah Peter (2019) observed that the gospel came with the impression that Christianity was a universal religion made for all humankind. He maintained that Christianity is the religion established in the world through Jesus Christ to whom all power is given in heaven and earth; therefore the law of any country can never stand against it, as God is the owner of heaven and earth and all that are in them. God by this religion forbids the destruction of twin-born children, as well as human sacrifice and commands us to preach against such customs and to rescue the victims from barbarous superstitions. Before the advent of Christianity, the Idoma people considered it an abomination to give birth to more than one child at a time. According to Amoni (1999:11), this was done because they felt that it was an abomination to the earth deity and the ancestral spirits. Ajobe (2019) maintained that:

[T] he traditional Idoma buildings were Ole-aje (mud houses) with ojokwunyi (thatched roofs) but through the work of the missionaries and development, such locally constructed houses have given way to solid cement walls, rectangular in shape with corrugated roofing sheets to match.

TABLE 1: Details of interviewees.

\begin{tabular}{|c|c|c|c|c|c|c|c|}
\hline $\mathrm{S} / \mathrm{N}$ & Name & Date & Town & Local government area & Occupation & Age & Gender \\
\hline 1 & Emmanuel Oyeche & 15 November 2018 & Ugbokpo & Apa & Civil servant & 45 & Female \\
\hline 2 & Atadojalyakubu & 30 September 2018 & Ogwule & Agatu & Trader & 60 & Male \\
\hline 3 & Adole Iyamu & 17 December 2018 & Obagaji & Agatu & Farmer & 55 & Female \\
\hline 4 & John Ademu & 20 December 2018 & Ayila & Agatu & Teacher & 60 & Male \\
\hline 5 & IjimbiliOnmata & 28 December 2018 & Odugbeho & Agatu & House wife & 50 & Female \\
\hline 6 & OkoNgbede & 23 January 2019 & Opa & Otukpo & Trader & 70 & Male \\
\hline 7 & UjataEbaiya & 29 January 2019 & Ugoju & Otukpo & Nurse & 45 & Female \\
\hline 8 & OkemeAdija & 04 February 2019 & Onipi & Otukpo & House wife & 65 & Female \\
\hline 9 & Onuhlchaba & 17 March 2019 & Onyegede & Ohimini & Farmer & 70 & Male \\
\hline 10 & Ela Ogenyi & 03 July 2019 & Obu-Otupka & Ogbadibo & Teacher & 50 & Female \\
\hline 11 & Atadogilkpe & 14 July 2019 & Ogemgem & Obi & Farmer & 67 & Male \\
\hline 12 & Okohldegwu & 16 May 2019 & Obotu & Obi & Teacher & 59 & Male \\
\hline 13 & Adejor Alice & 19 May 2019 & Ojahno & Obi & Pastor & 47 & Female \\
\hline 14 & AdocheOyigene & 25 May 2019 & Agenowa & Obi & Minister & 45 & Female \\
\hline 15 & Adamo Oteh & 08 April 2019 & Ulayi & Ado & Farmer & 70 & Male \\
\hline 16 & GbunuEnotshe & 12 April 2019 & Agila & Ado & Trader & 55 & Female \\
\hline 17 & Agbefa Ochi & 16 April 2019 & Ipole & Ado & Farmer & 69 & Male \\
\hline 18 & Adah Oko & 05 June 2019 & Olanyega & Opokwu & Nurse & 55 & Female \\
\hline 19 & GbunuEnotshe & 12 April 2019 & Agila & Ado & Trader & 55 & Female \\
\hline 20 & Agbefa Ochi & 16 April 2019 & Ipole & Ado & Farmer & 69 & Male \\
\hline 21 & Oyife Agnes & 19 April 2019 & Akpegede & Ado & Health worker & 56 & Female \\
\hline 22 & EjeOdo & 23 April 2019 & Obarike Ito & Oju & Tailoring & 45 & Male \\
\hline 23 & ApaluwaJobu & 31 April 2019 & Ikache & Oju & House wife & 70 & Female \\
\hline 24 & UlewaAdoyi & 06 May 2019 & Akpegedde & Oju & Hairdresser & 40 & Female \\
\hline 25 & ItodoEgwube & 15 June 2019 & Ameke & Oju & Farmer & 60 & Male \\
\hline
\end{tabular}


Another impact of Christianity on Idoma culture is name bearing. The Idoma people just like the Ogene people of Igala, bear the name of their ancestors because they claim to have close relationship with them and are believed to have reincarnated (Lewa 2019). Prior to the advent of Christianity, the traditional religion of the Idoma people was not intrinsically different from those of the neighbouring towns. The Idoma people represent a worshipping society in which 'everything in native life has a religious significance' (Anizoba \& Johnson 2021). There was a clear-cut idea of God (Owo-icho) the creator and sustainer of the universe and all things in it. However, 'Owo-icho' has a cultic system. Worship was predominantly directed to the environmental gods, which controlled the day-to-day activity of the people. According to Isaac (2016):

$[T]$ he religious ideas of the town through which he passed, their language, manners and customs closely resemble those of Kogi but as it is to be expected that the people are deeply sunk in idolatry and superstition. Nearly every house has its own god moulded in mud and placed with other objects of adoration in a small porch annexed to the dwelling house. Goats and fowls are offered to these plentifully, both to implore their aid in matters of daily life as well as to secure their protection against malevolent powers. Such is heathenism. (p. 15)

In spite of its crude nature, it was this traditional religious system that prepared the minds of the people for the acceptance of Christianity. Today, the implication of Christianity on Idoma traditional religion is visible in the numerous churches (both mainline and Pentecostal), which have replaced traditional shrines. Worship, sacrifices, symbols and all religious rites are not directed to the supreme God (Owo-icho) in churches. The minor deities and the ancestors are left behind to fend for themselves or starve to death.

Indeed, they (the gods) are gradually becoming powerless each passing day as the Christian population continues to increase by leaps and bounds. Before the coming of Christianity, the Idoma people had a strong belief that life continues after death of the physical body. Ulewah and Ebo (pers. comm., 2018) observed that: 'The Idoma people believe in the transmigration of souls, a sad example of which came under our notice a short time ago'.

\section{Christian impact on social institutions}

The influence of Christianity brought about both negative and positive changes to the social institutions of the traditional Idoma people. This has modified and transformed the practice of title taking, the filial obligation and traditional system of marriage, slavery, human sacrifice and education. For the Idoma people, western education was mainly focused on men while less attention was given to women education. As we have mentioned previously, the pioneer missionary agents who laboured in Idoma land described the town as 'a land of kings' because of the large number of titled men in the community. For instance, in 1890, it was estimated that about 220 men were title holders in the town. Right from the beginning, Christian missionaries fought against all forms of title taking because of the traditional rituals associated with the custom. According to Pastor Edward Philips (pers. comm., 2018), 'Slaves and other animals were killed to propitiate the gods before he (the titled man) can be recognised as the 'king' and to bestow titles to any befitting member of Idoma society'. The people themselves justified their beliefs and practice by arguing that:

$[I] \mathrm{t}$ is the custom of our ancestors; and we, their children, will be regarded as degenerate ones if we should either swerve or depart from that which was being done from countless ages back. (Oyigebe 2007:n.p.)

Christianity stamped out the practice of taking titles and the participation of its adherents in the rituals associated with the custom.

Another contentious issue in the traditional marriage system was the idea of polygamy which was then prevalent. In the past, polygamy was a mark of enhanced social status. As Rev Julius (2018) has observed, 'The passion to multiply wives here (at Idoma) is very great. There is hardly any young man of fair means who has in his possession three or four wives with hopes of increasing the number as time advances. For Christian missionary agents and the colonial masters, however, the practice of polygamy was an obstacle to the Gospel and Christian family life. Another area where Christianity demonstrated the social aspect of the Gospel is in the fight against domestic slavery and the obnoxious customs of human sacrifice. Domestic slavery as we have mentioned before is the traditional practice of the Idoma people that seems to be anti-social as a result of the influence of Christianity.

\section{Western education}

The missionaries in their evangelisation of Idoma land came also with education. The type of education introduced in the course of their missionary endeavours was alien to the people; there were some hitches in the initial stage of creating a solid foundation for the schools and education in Idoma land. Thus, during the initial stage, it was not easy for a very long time to get children to attend mission schools in Idoma land. The people would not allow their children to waste time in what they called 'white man's school'. Instead, they sent the boys to the farm and the girls helped their mothers in domestic chores. Nonetheless, the people later began to change their attitude towards education. Between 1940 and 1960, there was a tremendous increase in the enrolment of pupils in these mission schools. Another motivating factor that led Idoma people to develop an interest in western education was the intended need to improve their quality of life such as becoming professional in certain areas of their lives through education. Based on the above reason, Idoma communities saw the urgent need to have educated persons in their midst; and those who collaborated with the demands of western education or who joined forces with the colonial masters advanced in life more than those who never did. Adibe (2008a) succinctly expressed his view on this fact as follows:

$[T]$ he new education opened new vistas for new ideas and possibilities, and the need to acquire English language became a 
new urge for those who had foresight. Incidentally, the clamour for western education was as a result of the people's receptivity to change and the urge for greener pasture. (p. 15)

\section{Urbanisation and industrialisation}

The process of the concentration of populations in the urban centres is linked closely to the processes of economic, political, cultural and religious changes. Since the industrial revolution and rise of capitalism, the phenomenon of urbanisation has taken on a universal character. Today, the most densely populated cities in Nigeria are located in the headquarters or capitals of different states and some suburbs or satellite towns. These places are densely populated because the expectations of improved new social and economic life are high. More so, the cities became focal points for political, economic and judicial activities, which attracted rural dwellers. The development of urbanisation and industrial revolution that led to the influx of people from the countryside to the cities for improved economic and social life, brought along side its own negative influences on the African societies. Quacoopome (1987:189-190) argued that the advent of western civilization has brought in its wake urbanization and industrialization which have disturbed and transformed the relative peaceful and stable order of the rural areas'. It is also in this light that Beauchemin, Henry and Schoumaker (2004:3) argued that 'the conventional view perceives urbanization as an "explosive" process for which migration is mainly responsible, and which has a negative impact'.

\section{Growth in media communication system}

Mass media is regarded as an agent of social change which has had a great influence on the lives of different people. Mass media refers to communication whether written, broadcast or spoken that reaches a large audience. This includes television, radio, advertising, movies, the Internet, newspaper, magazines and so forth. Media communication is a significant force in modern culture; sociologists refer to this as a mediated culture where media reflects and creates the culture. Communities and individuals in Idoma land are fed constantly with messages from multitude of sources like television, billboards, magazines, cinema and so on. While opinions vary as to the extent and type of influence the mass media wields, all sides agree that mass media is a permanent part of modern culture. Mass media provides some good mutual services in our modern societies; this development was noted by Awolalu and Dopamu (1987:284) when they stated that 'Christians and traditionalists use the instruments to their own advantage when they publicize their programmes'. Adibe (2008b:303) clarified this development when he remarked that 'the ideas from mass media may reenforce or disorganize a prior culturally valued knowledge. Hence, mass media is a means of social formation or disinformation'. It is noticeable that radios and televisions and other means of mass media, which come in local languages together with other media apparatus in no small measure, promote acculturation in African culture in general and in Idoma land in particular.

\section{Findings of the research}

The Idoma culture was rich and intact before the advent of Christianity, but the growth of Christianity with its education in the area introduced religious and social changes, which affected the people positively as well as negatively. One of the positive impacts of Christianity on Idoma culture was the abolition of killing of twins. Before the advent of Christianity, the Africans and Idoma people in particular considered it an abomination to give birth to more than one child at a time. According to Ugwu (1999:58), 'this was done because they felt that it was an abomination to the earth deity and the ancestral spirits'. With the effort of the missionaries and Mary Slessor in particular, this unjust practice ended in Nigeria and Idoma land. The eradication of human sacrifice was another positive impact of Christianity on Idoma culture. This was normally carried out in the form of atonement when there was an abomination in the land leading to a breach of harmony between the spirit world and the communities. A good example can be demonstrated with the burial of chiefs along with slaves who would serve them (the chiefs) in the underworld. The Christian missionaries also provided health delivery services through the establishment of hospitals. These include Grimad Hospital Adupi, Immaculate Heart Maternity Dispensary, Orkam, Idada Christian Hospital Apa, Holley Memorial Hospital Ochadamu, to name a few.

The dwindling in the ancestral veneration made the ancestors not to function well before the advent of Christianity. If a man plans evil against any member of his/her family or a married woman seduces another man in her life, both must face the wrath of the ancestors. Today, the African culture of polygamy has given way to monogamy. In fact today, the educated Idoma feel that it is shameful to have more than one wife. The implication of this according to Ilogu (1974) is that:

[T] he emphasis of the church on one man one wife has also added to the number of women who remained unmarried. Some of these in despair would also go into the towns as prostitutes. (p. 97)

Another negative impact of Christianity on Idoma culture is name bearing. The traditional Idoma names helped to identify people's family background; and events that occurred at the time of birth of a person, which has been influenced by the advent of Christianity in the area. Adamo (2005:10) also observed in respect with the above that among the Africans, names are symbolic; they represent the totality of what the persons are. The Yoruba people of Nigeria regard names as having special power. Names are chosen with great care because such names may represent one's prayer to God and to the divinities. Names may represent the parents' experience in life or during birth. Most of these names are not just given without meanings.

Today, Idoma Christians refuse to take Idoma names at sacraments like baptism, insisting that such names could not 
be a part of Christian heritage. Foreign names like Theophilus, Daniel, Maxwell, Roseline and many more are preferred to native names such as Ifiene (in the regime), Oyalewa (he who bares seed does not die), Ikani (may be alive), Okoliko (on the farm), Ojonoka (God is a strategist) and Ocholi (iron) to name a few. This is the most dangerous cultural change that is taking place in the Idoma society. Obotu (2016:44) stated that 'one cannot estimate correctly the havoc that will be caused to our culture in the next 100 years if the practice continues'. In concurrence with the above, Ugwu (1999:56) stated that 'this undoubtedly has provided room for moral decadence and other vices in our social system'. What this means is that people hide under the cover of Christianity to assert non-oath-taking when they commit evil. According to Odiniya (2011), Igala drumming and dancing is divided into four. They are (1) royal music such as Odechi and UkagaOnu, (2) entertainment or social music such as Ichabada, Ugwolo, Olele, Agbaka and Agale, (3) the cleansing and ritual music are Ogba, Iyogwu and Oye and (4) the dual music. These are the ones that can feature on different occasions such as Odechi which can feature at traditional second burial etc. He further stated that the Odechi, Ogba, Iyogu and Oye have lost most of its profit to Christianity and Islam.

\section{Conclusion}

Christianity, Islam and other religions have influenced many traditional beliefs and practices across the country, and the Idoma people are no exception. Despite this, many of them continue to believe in the alekwu, which are considered ancestral spirits and serve as a link between the living and the dead. Like any other Nigerian community, the Idoma community is a dynamic society that is sensitive to change. In both positive and negative ways, Christianity had an indelible imprint on the cultural traditions of the Idoma people and Nigerian culture. Changes happen as a result of both conscious and unconscious behaviours. One culture has an impact on the other, and vice versa. Before the arrival of Christianity, the Idoma culture was rich and intact, but the spread of Christianity and education brought religious and social changes to the area, which had both positive and negative effects on the people.

\section{Acknowledgements}

The authors express their gratitude towards Dr Kingsley Uwaegbute and Dr Damian Odoh, who contributed immensely on the background of this study. They also wish to acknowledge the financial help rendered by Prof Beyers in enabling the publication of this article.

\section{Competing interests}

The authors declare that they have no financial or personal relationships that may have inappropriately influenced them in writing this article.

\section{Authors' contributions}

The area of the study is the present home of the second author (E.M.J.) who provided the primary data for the study, while the first author (E.C.A.) provided the secondary sources of data collection. Topics were shared among the two authors who wrote the article. This study, which is a part of the undergraduate project by E.C.A. and E.M., was presented to the Department of Religion and Cultural Studies, University of Nigeria, Nsukka.

\section{Ethical considerations}

This article followed all ethical standards for research without direct contact with human or animal subjects.

\section{Funding information}

This research received no specific grant from any funding agency in the public, commercial, or not-for-profit sectors.

\section{Data availability}

Data sharing is not applicable to this article as no new data were created or analysed in this study.

\section{Disclaimer}

The views and opinions expressed in this article are those of the authors and do not necessarily reflect the official policy or position of any affiliated agency of the authors, and the publisher.

\section{References}

Adamo, J.O., 2005, 'The concept of death and hereafter in Yoruba traditional religion', Bulletin of West African Religion (WAR), 17(2), 10.

Adibe, A.P., 2008a, 'The encounter between Christianity and traditional religion among the Yoruba of South West, Nigeria', in O.E. Alana (ed.), Uma Journal of Philosophy \& Religious Studies, vol. 3, no. 10, pp. 234-247, Nathadex, Ilorin.

Adibe, E.G., 2008b, 'Mysticism in African traditional religion: Northern Igbo cultural area experience', Unpublished Ph.D research comprehensive, Department Of Religion, University Of Nigeria, Nsukka.

Agha, U.A., 2012, Religion and culture in a permissive society, Idika, Enugu.

Anizoba, E.C. \& Johnson, E.M., 2021, 'Patterns of traditional religious and cultural practices of the Idoma people of Nigeria', Journal of Filosofia Theoretica: Journal of African Philosophy, Culture and Religions 10(2), 11. https://doi.org/10.4314/ of African $10 \mathrm{i} 2.1$

Anizoba, E.C., Onyeume, A.O. \& Ezeanya, O.C.P., 2021, 'Critical examination of traditional worship systems among Igbo people of Nigeria: Study of Akpo community', TRAMES 25(75/70), 83-99. https://doi.org/10.3176/tr.2021.1.06

Henry, S., Schoumaker, B. \& Beauchemin, C., 2004, 'The impact of rainfall on the first out-migration: A multi-level event - history analysis in Burkina Faso', Population and Environment 25, 423-460.

Ilogu, E., 1974, Christianity and Igbo culture: A study of the interaction of Christianity and Igbo culture, Nok, New York, NY.

Isaac, 2016, Theology and identity: The impact of culture upon Christian thought in the second century and modern Africa, Regnum, Oxford.

Odiniya, F., 2011, The history and tradition of Okenyi (The Igala cultural heritage), Cuca Communication and Associates Limited, Ankpa.

Omoregbe, J.I., 1999, Comparative religion: Christianity and other world religions in dialogue, Joja Educational Research and Publishers Ltd., Lagos.

Omosade Awolalu, J. \& Dopamu Adelumo, P., 1987, West African traditional religion, Onibonoje Press \& Book Industries (Nig) Ltd., Ibadan.

Quacoopome, T.N.O., 1987, West African traditional religion, African University, Ibadan. Ugwu, C.O.T., 1999, Man and his religion, Chukka Education, Nsukka. 